\title{
PENGARUH PROFITABILITAS, LEVERAGE DAN LIKUIDITAS TERHADAP KINERJA LINGKUNGAN
}

(Studi pada Badan Usaha Milik Negara (BUMN) Sektor Manufaktur Periode 2009-2013)

\author{
Agus Widarsono \\ Cantika Putri Hadiyanti \\ (Universitas Pendidikan Indonesia)
}

\begin{abstract}
ABSTRAK
Penelitian ini bertujuan untuk menguji dan mendapatkan bukti empiris mengenai faktor-faktor yang berpengaruh terhadap kinerja lingkungan secara parsial dan simultan. Faktor-faktor yang diteliti dalam penelitian ini adalah profitabilitas, leverage dan likuiditas. Metode penelitian yang digunakan adalah metode deskriptif verifikatif. Dengan pengujian verifikatif menggunakan regresi berganda (multiple regression), pengujian parsial (uji t) dan pengujian simultan (uji F). Data yang digunakan merupakan data sekunder yaitu laporan tahunan perusahaan dan laporan hasil PROPER Kementrian Lingkungan Hidup yang dijadikan sampel dalam penelitian. Sampel penelitian merupakan 11 perusahaan Badan Usaha Milik Negara (BUMN) Tahun 2009-2013 yang diambil dengan menggunakan metode purposive sampling. Hasil penelitian ini menunjukkan bahwa profitabilitas, leverage dan likuiditas berpengaruh secara tidak signifikan terhadap kinerja lingkungan secara parsial. Serta profitabilitas, leverage, dan profitabilitas berpengaruh secara tidak signifikan terhadap kinerja lingkungan secara simultan.
\end{abstract}

\section{Kata kunci : Profitabilitas, leverage, likuiditas, dan kinerja lingkungan}

\section{PENDAHULUAN}

Secara umum terdapat 3 tujuan utama dari perusahaan atau lebih dikenal dengan triple bottom line, yaitu profit, people, dan planet. Dari tinjauan ini jelas digambarkan bahwa fokus BUMN pun mulai beralih dari yang hanya sekedar menekankan pada profit (untuk sumber pendapatan negara yang berasal dari pendapatan non pajak) menjadi dalam cakupan yang lebih luas, yaitu lingkungan baik sosial maupun lingkungan hidup.

Kunci dan tujuan dari integrasi antara kinerja ekonomi dan kinerja lingkungan dalam konsep green manufacturing adalah kemunculan darisustainable development atau perkembangan yang berkelanjutan dimana kinerja ekonomi yang baik tidak hanya terbatas dalam perspektif jangka pendek namun juga perspektif jangka panjang. Harapannya, dengan aplikasi konsep green manufacturing ini akan muncul integrasi antara produk perusahaan yang tetap memiliki kualitas namun produk tersebut merupakan produk yang ramah lingkungan baik dalam proses produksinya maupun produk itu sendiri. Sehingga 
dengan konsep ini perusahaan dapat mencapai triple bottom line yang menjadi tujuan dasar perusahaan begitu pula dengan BUMN.

Tetapi kepedulian akan lingkungan sebenarnya juga muncul akibat berbagai dorongan dari pihak luar perusahaan (Berry dan Rondinelli, 1998 dalam Ja'far dan Arifah, 2006), antara lain: pemerintah, konsumen, stakeholders dan pesaing. Untuk menindak lanjuti berbagai dorongan ini, maka perlu diciptakan pendekatan secara proaktif dalam meminimalkan dampak lingkungan yang terjadi. Hasil akhir tindakan proaktif manajemen lingkungan tersebut adalah terciptanya kinerja lingkungan perusahaan yang baik.

Salah satu tindakan yang dilakukan oleh pemerintahan Indonesia dalam hal praktek manajemen lingkungan yaitu Program Penilaian Peringkat Kinerja Perusahaan. Pemerintah melalui Kementrian Lingkungan Hidup (KLH) melalui Program Penilaian Peringkat Kinerja Perusahaan (PROPER) memberikan penilaian kepada perusahaan-perusahaan di Indonesia atas aktivitas pengelolaan lingkungan yang dilakukan oleh perusahaan tersebut. Aktivitas pengelolaan lingkungan perusahaan akan tercermin dalam kinerja lingkungannya. Penilaian kinerja lingkungan ini dapat dikatakan independen dan objektif karena dilakukan oleh pihak eksternal.

Sistem peringkat PROPER mencakup pemeringkatan perusahaan dalam lima peringkat warna guna memudahkan komunikasi dengan stakeholders dalam menyikapi hasil kinerja penaatan masing-masing perusahaan. Pemeringkatan kinerja lingkungan perusahaan juga menunjukkan seberapa besar kepedulian perusahaan terhadap isu-isu lingkungan. Perusahaan yang dapat peringkat baik, tentu memiliki kepedulian lingkungan yang lebih besar dibanding perusahaanperusahaan yang mendapat peringkat buruk. Kepedulian perusahaan terhadap isu lingkungan sangat berkaitan dengan karakteristik perusahaan tersebut. Karakteristik perusahaan sendiri dapat dilihat dari ukuran perusahaan, ukuran dewan komisaris, international ownership, profitabilitas, leverage, public ownership atau profile (Anggi, 2011).

Kondisi ekonomi sebuah perusahaan dapat diketahui kekuatan dan kelemahannya melalui rasio-rasio keuangan seperti rasio profitabilitas, leverage dan likuiditas.Terdapat 33 BUMN yang bergerak dalam industri pengolahan/manufaktur dan beberapa diantaranya merupakan BUMN yang strategis. rata-rata rasio profitabilitas, leverage, dan likuiditas dari bumn sektor manufaktur dalam keadaan cukup menunjukkan angka yang baik untuk keadaan bumnnya itu sendiri. Untuk rasio profitabilitas angka 0,0668tersebut menunjukkan bahwa penghasilan bersih yang di peroleh adalah sebesar 6,68\%dari total aset. Untuk rasio leverage angka 0,8300tersebut menunjukkan bahwa aset sebesar $83 \%$ di biayai dari hutang perusahaan. Dan untuk rasio likuiditas angka 2,5613atau 256,13\% menunjukan Setiap Rp 1,00 hutang lancar di jamin atau di tanggung oleh $\mathrm{Rp} 2,56$ aset lancar, untuk prinsip kehati-hatian nya sendiri Current ratio (likuiditas) karena angka nya melebihi 200\% atau 2:1 maka di anggap mendekati kategori baik. (sumber: www.bumn.go.id)

Namun, sepertinya masih banyak yang harus di perhatikan oleh BUMN terkait kinerja lingkungan. Karena seperti yang telah dilansir di Keputusan Menteri Lingkungan Hidup Nomor 349 Tahun 2013 tentang Hasil Penilaian Peringkat Kinerja Perusahaan dalam Pengelolaan Lingkungan Hidup (PROPER) Tahun 2012 - 2013: Dari 356 Badan Usaha Milik Negara (BUMN) yang masuk 
dalam mekanisme PROPER,terdapat 49 Perusahaan yang berperingkat TIDAK TAAT dalam pengelolaan lingkungan (5 perusahaan berperingkat HITAM dan 44 perusahaan berperingkat MERAH). Untuk BUMN sektor manufaktur sendiri, dari tahun 2009 sampai 2013 jumlah perusahaan yang mendapatkan PROPER mengalami peningkatan setiap tahunnya. Jumlah BUMN sektor manufaktur yang mendapatkan peringkat PROPER adalah sebanyak 12 perusahaan di tahun 2009, 11 perusahaan ditahun 2010, 16 perusahaan di tahun 2011, 16 perusahaan di tahun 2012, dan 21 BUMN di tahun 2013. (sumber: www.menlh.go.id)

Mengacu pada latar belakang dan fenomena yang terjadi, peneliti ingi mengetahui pengaruh profitabilitas, leverage, dan likuiditas terhadap kinerja lingkungan BUMN sektor manufaktur periode 2009-2013. Hasil penelitian ini diharapkan dapat memberikan kontribusi atau sumbangan untuk pengembangan ilmu pengetahuan, khususnya yang berkaitan dengan bidang akuntansi manajemen. Adapun manfaat praktis dari penelitian ini adalah untukmemberikan gambaran mengenai kinerja keuangan yang baik yang dilihat dari profitabilitas, leverage, dan likuiditas akan dapat meningkatkan motivasi bagi perusahaan dalam meningkatkan kinerja lingkungan yang baik di perusahaan.

\section{KAJIAN PUSTAKA}

Menurut Ikhsan, Arfan (2009:308) kinerja lingkungan adalah hasil yang dapat diukur dari sistem manajemen lingkungan, yang terkait dengan kontrol aspek-aspek lingkungannya. Standar Nasional Indonesia menyatakan bahwa kinerja lingkungan merupakan hasil yang terukur dari manajemen organisasi terhadap aspek lingkungannya (SNI, 2005). Secara garis besar kinerja lingkungan dapat diukur dengan dua cara, yang pertama adalah dengan melakukan pengukuran secara mandiri dengan menetapkan parameter atau indikator yang menjadi dasar penilaian kinerja. Cara yang kedua adalah melalui lembaga eksternal yang independen, yang biasanya dilakukan pemeringkatan kinerja dari yang terbaik sampai terburuk.

Secara kelembagaan di Indonesia, instansi yang mengatur mengenai masalah lingkungan adalah Kementrian Lingkungan Hidup dan di daerah (Environmental Protection Agency), pemeringkatan kinerja lingkungan perusahaan di Indonesia sendiri dilakukan oleh Kementrian Lingkungan Hidup melalui Program Penilaian Peringkat Kinerja Perusahaan dalam Lingkungan Hidup atau yang biasa disebut PROPER.

Profit merupakan hasil kebijakan manajemen, maka kinerja perusahan dapat diukur dengan profit. Adapun kemampuan perusahaan untuk menghasilkan laba disebut profitabilitas. Pengertian profitabilitas menurut Gitman (2003:599) adalahhubungan antara pendapatan dan biaya yang dihasilkan dengan menggunakan aset perusahaan - baik saat ini dan tetap - dalam kegiatan produktif..

Sedangkan Menurut Kasmir (2008:196) rasio profitabilitas merupakan rasio untuk menilai kemampuan perusahaan dalam mencari keuntungan.

Setiap perusahaan dalam menjalankan kegiatan operasionalnya sehari-hari pasti membutuhkan modal. Modal tersebut berasal dari modal sendiri maupun modal yang berasal dari pinjaman. Perusahaan yang menggunakan sumber dana dari luar untuk membiayai operasional perusahaan baik yang merupakan sumber 
pembiayaan jangka pendek maupun jangka panjang merupakan penerapan dari kebijakan leverage.

Sedangkan menurut Lukman Syamsuddin (2001:89) Leverage adalah kemampuan perusahaan untuk mengunakan aktiva atau dana yang mempunyai beban tetap (fixed cost assets or funds) untuk memperbesar tingkat penghasilan (return) bagi pemilik perusahaan. Menurut Hanafi (2008: 40) rasio utang/solvabilitas/leverage ini mengukur kemampuan perusahaan memenuhi kewajiban jangka panjangnya. Perusahaan yang tidak solvabel adalah perusahaan

Likuiditas suatu perusahaan berhubungan erat dengan masalah kemampuan suatu perusahaan untuk memenuhi kewajiban finansialnya yang harus segera dipenuhi. Untuk dapat memenuhi kewajiban tersebut, maka perusahaan harus mempunyai alat-alat likuid yang berupa aktiva lancar yang jumlahnya harus lebih besar dari jumlah kewajiban-kewajiban yang harus segera dipenuhi yang berupa hutang-hutang lancar. Pengertian likuiditas menurut menurut Sutrisno (2000:18), adalah kemampuan perusahaan untuk memenuhi kewajiban yang harus segara dipenuhi.

Sedangkan menurut Weston dalam Kasmir (2008:130) rasio likuiditas (liquidity ratio) merupakan rasio yang menggambarkan kemampuan perusahaan dalam memenuhi kewajiban (utang) jangka pendek. Artinya jika perusahaan ditagih, maka perusahaan akan mampu untuk memenuhi utang tersebut terutama utang yang sudah jatuh tempo.

Penelitian sebelumnya terkait profitabilitas, leverage, dan likuiditas terhadap kinerja lingkungan telah dilakukan diantaranya olehSusi Sarumpaet (2005) tentang hubungan antara kinerja lingkungan dengan kinerja keuangan, dan hasilnya adalah kinerja lingkungan tidak berhubungan secara signifikan dengan kinerja keuangan, tetapi berhubungan signifikan dengan porsi saham publik, ukuran perusahaan dan ISO14001.Dietrich Earnhart \& Lubomir Lizal (2006) tentang efek dari kepemilikan dan kinerja keuangan terhadap kinerja keungan perusahaan, yang memberikan bukti bahwa kesuksesan kinerja keuangan meningkatkan kinerja lingkungan di masa depan, yang dilihat dari likuiditas. Serta peningkatan kepemilikan benar-benar meningkatkan kinerja lingkungan relatif pada perusahaan di Ceko. Anggi Martia (2011) tentang pengaruh Roa, Total Aset, Dan Sertifikasi Iso 14001 Terhadap Kinerja Lingkungan, yang menunjukkan bahwa dengan tingkat signifikansi 5\% secara simultan semua variabel independen tidak berpengaruh secara signifikan terhadap variabel dependen dan secara parsial ROA dan sertifikasi ISO 14001 berpengaruh positif signifikan terhadap kinerja lingkungan, sedangkan variabel independen lain seperti total aset tidak berpengaruh positif signifikan terhadap kinerja lingkungan. Connors, Elizabeth \& Gao, Lucia S. (2011) tentang kinerja lingkungan perusahaan pengungkapan dan leverage yang menemukan hubungan yang signifikan antara leverage, kinerja lingkungan dan peningkatan pengungkapan pada persamaan model simultan, bila dibandingkan dengan hasil yang diperoleh dalam model OLS.

Hasil penelitian yang berbeda atas berbagai hipotesis antar satu peneliti dengan lainnya mendorong dilakukannya penelitian ini.Perbedaan penelitian ini dengan penelitian sebelumnya terletak pada variasi variabel yang diduga berpengaruh terhadap kinerja lingkungan perusahaan, subyek penelitian yang digunakan, indikator yang digunakan untuk mengukur setiap variabel yang diteliti, serta periode penelitian. Penelitian ini menggunakan variabel 
profitabilitas, leverage, dan likuiditasdengan subyek perusahaan BUMN sektor manufaktur periode 2009-2013.

Berdasarkan kajian literatur serta beberapa penelitian terdahulu, maka peneliti mengindikasikan profitabilitas, leverage, dan likuiditas sebagai variabel yang memperngaruhi kinerja lingkungan pada BUMN sektor manufaktur. Adapun hipotesis dari penelitian ini adalah sebagai berikut:

$\mathrm{H}_{1}$ :Profitabilitas, leverage, dan likuiditas mempunyai pengaruh terhadap kinerja lingkungan secara parsial.

$\mathrm{H}_{2}$ :Profitabilitas, leverage, dan likuiditas mempunyai pengaruh terhadap kinerja lingkungan secara simultan.

\section{METODE PENELITIAN \\ Populasi dan Sampel}

Dalam penelitian ini yang menjadi populasi adalah Badan Usaha Milik Negara (BUMN) sektor manufaktur yang terdaftar di kementerian BUMN selama periode 2009-2013. Dari keseluruhan populasi, tidak semuanya akan diteliti. Teknik sampling yang digunakan adalah purposive sampling, yaitu teknik penentuan sampel dilakukan secara tidak acak yang informasinya diperoleh dengan menggunakan pertimbangan tertentu (Indriantoro dan Supomo, 2012). Adapun pertimbangan-pertimbangan dalam penelitian ini diantaranya:

1. BUMN sektor manufaktur yang mempublikasikan laporan keuangannya di Kementrian BUMN dan di situs web masing-masing.

2. BUMN sektor manufaktur yang telah mempunyai peringkat PROPER di Kementrian Lingkungan Hidup dari perode 2009-2013.

Berdasarkan pertimbangan tertentu yang telah ditetapkan, dari total populasi 33 BUMN, diperoleh sejumlah 11 sampel BUMN yang memenuhi pertimbangan.Maka jumlah observasi dalam penelitian ini sebanyak 5 tahun observasi $\mathrm{x} 11$ sampel penelitian $=55$ observasi.

\section{Variabel dan Pengukuran}

Variabel dalam penelitian ini menggunakan variabel bebas dan terikat.Variabel bebas merupakan tipe variabel yang menjelaskan atau mempengaruhi variabel lain (Indriantoro dan Supomo, 2012).Variabel bebas dalam penelitian ini adalahprofitabilitas, leverage, dan likuiditas.

Profitabilitas merupakan suatu perhitungan yang bertujuan untuk mengetahui tingkat laba yang diperoleh perusahaan dengan berdasarkan komponen-komponen yang ada dalam perusahaan pada tingkat penjualan, aset dan modal saham tertentu. Salah satu rasio yang dipakai utk mengukur profitabilitas adalah return on asset. Rasio profitabilitas ini akan memberikan gambaran dan jawaban akhir tentang tingkat efektivitas pengelolaan perusahaan. Menurut Hanafi (2008: 42), rasio ROA bisa dihitung sebagai berikut:

$$
\text { Return on Asset }=\frac{\text { Laba Bersih }}{\text { Total Asset }}
$$

Leverage merupakan rasio untuk mengukur kemampuan perusahaan memenuhi kewajiban jangka panjangnyaakan memberikan tiga dampak penting yaitu menghimpun dana melalui utang, kreditor melihat ekuitas atau dana yang 
diberikan oleh pemilik sebagai batas pengaman, dan hasil yang diperoleh dari aset perusahaan lebih tinggi daripada tingkat bunga yang dibayarkan.

Menurut Brigham dan Houston (2010: 143) Rasio total utang terhadap total aset, yang umumnya disebut rasio utang (debt ratio), mengukur persentase dana yang diberikan oleh kreditor seperti dinyatakan berikut ini:

$$
\text { Rasio Utang }=\frac{\text { Total Utang }}{\text { Total Aset }}
$$

Likuiditas merupakan rasio yang menggambarkan kemampuan perusahaan dalam memenuhi kewajiban (utang) jangka pendek.Rasio-rasio ini dapat dihitung melalui sumber informasi tentang modal kerja yaitu pos-pos aktiva lancar dan utang lancar.Menurut Brigham dan Houston (2010: 134) rasio likuiditas yang utama adalah rasio lancar (current ratio) yang dihitung dengan membagi aset lancar dengan kewajiban lancar, seperti dinyatakan berikut ini:

$$
\text { Rasio Lancar }=\frac{\text { Aset Lancar }}{\text { Kewajiban Lancar }}
$$

Sementara itu, variabel terikat merupakan tipe variabel yang dijelaskan atau dipengaruhi oleh variabel bebas. Variabel terikat dalam penelitian ini adalah kinerja lingkungan.kinerja lingkungan adalah hasil yang dapat diukur dari sistem manajemen lingkungan, yang terkait dengan kontrol aspek-aspek lingkungannya.Secara kelembagaan di Indonesia, instansi yang mengatur mengenai masalah lingkungan adalah Kementrian Lingkungan Hidup dan di daerah (Environmental Protection Agency),pemeringkatan kinerja lingkungan perusahaan di Indonesia sendiri dilakukan oleh Kementrian Lingkungan Hidup melalui Program Penilaian Peringkat Kinerja Perusahaan dalam Lingkungan Hidup atau yang biasa disebut PROPER.

Untuk dapat mempermudah komunikasi dengan para stakeholders dalam menyikapi hasil kinerja pengelolaan lingkungan perusahaan, maka pemeringkatan kinerja lingkungan dikelompikan kedalam lima peringkat warna sebagai simbol pemeringkatan. Pada umumnya peringkat menggunakan huru mutu, angka dan bintang. Dalam aspek komunikasi penggunaan peringkat warna akan lebih mudah dipahami dan diingat oleh masyrakat. Penggunaan peringkat warna juga memberikan insentif tersendiri bagi reputasi masing-masing perusahaan.

Adapun 5 peringkat kinerja pengelolaan lingkungan dalam PROPER adalah sebagai berikut:

\begin{tabular}{|c|c|c|c|c|c|}
\hline $\begin{array}{l}\text { Tingkat } \\
\text { Penaatan }\end{array}$ & \multicolumn{3}{|c|}{ Alternatif Peringkat } & \multicolumn{2}{|c|}{$\begin{array}{l}\text { Efek publikasi yang } \\
\text { diharapkan }\end{array}$} \\
\hline \multirow{2}{*}{$\begin{array}{l}\text { Lebih } \\
\text { Dari Taat }\end{array}$} & $\mathrm{A}$ & $\diamond \diamond \diamond \diamond$ & Emas & \multirow{2}{*}{$\begin{array}{l}\text { Insentif } \\
\text { Reputasi }\end{array}$} & \multirow{2}{*}{$\begin{array}{l}\text { Penghargaan } \\
\text { Stakeholder }\end{array}$} \\
\hline & $\mathrm{B}$ & $\bullet \bullet \bullet$ & Hijau & & \\
\hline Taat & $\mathrm{C}$ & $\bullet \bullet$ & Biru & & \\
\hline \multirow{2}{*}{$\begin{array}{l}\text { Belum } \\
\text { Taat }\end{array}$} & $\mathrm{D}$ & $\diamond$ & Merah & \multirow{2}{*}{$\begin{array}{l}\text { Disinsentif } \\
\text { Reputasi }\end{array}$} & \multirow{2}{*}{$\begin{array}{l}\text { Tekanan } \\
\text { Stakeholder }\end{array}$} \\
\hline & $E$ & $\bullet$ & Hitam & & \\
\hline
\end{tabular}

Tabel Peringkat PROPER

Sumber: www.menlh.go.id 


\section{HASIL DAN PEMBAHASAN}

\section{Uji Kelayakan Model Regresi}

Pengujian hipotesis dilakukan dengan menggunakan analisis regresi berganda. Uji asumsi klasik yang dipersyaratkan untuk model regresi telah dilakukan dan diperoleh hasil olah data dengan Eviews 7,sebagai berikut:

a.) Uji normalitas pada penelitian ini menggunakan pengujian plot Jarque-Bera dan grafik distribusi normal.

Tabel Uji Normalitas

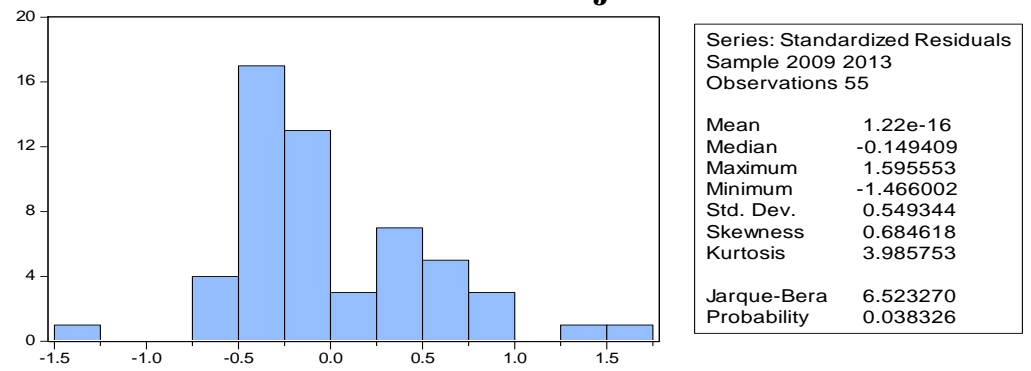

Hasil pengujian di atas menunjukkan bahwa data pada penelitian ini berdistribusi normal. Hal ini ditunjukkan oleh bahwa nilai JB $(6,523)$ $<\mathrm{X}^{2}$ tabel $(7,815)$ maka dapat disimpulkan bahwa residual berdistribusi normal.

b.) Uji multikolinearitas dilihat dari nilai koefisien korelasinya. Berikut adalah hasil pengujian multikolinearitas pada penelitian ini:

Tabel Hasil Uji Multikolinearitas

\begin{tabular}{|c|c|c|c|}
\hline 1.000000 & -0.589025 & 0.419545 & 0.218232 \\
\hline-0.589025 & 1.000000 & -0.149310 & -0.305801 \\
\hline 0.419545 & -0.149310 & 1.000000 & 0.124533 \\
\hline 0.218232 & -0.305801 & 0.124533 & 1.000000 \\
\hline
\end{tabular}

Dari tabel diatas dapat dilihat nilai koefisien korelasinya antar variabel independen dibawah 0,80 dengan demikian data dalam penelitian ini tidak terjadi masalah multikolinearitas (Sofyan,2008). Maka dapat disimpulkan bahwa variabel-variabel penelitian ini tersebut tidak mengalami multikolinearitas.

c.) Uji heteroskedestisitas dapat dilakukan dengan Uji Park.

Tabel Hasil Uji Heterokedastisitas

\begin{tabular}{|l|l|}
\hline t-statistik & $\mathrm{p}$-Value \\
\hline-0.927232 & 0.3582 \\
\hline 1.879805 & 0.0659 \\
\hline-4.936224 & 0.0000 \\
\hline 0.359817 & 0.7205 \\
\hline
\end{tabular}

Dari output diatas dapat kita lihat bahwa koefisien masingmasing variabel independen bersifat tidak signifikan, maka dengan demikian dapat ditarik kesimpulan bahwa pada model regresi ini tidak terjadi heteroskedakstisitas. 
d.) Dalam pengujian autokorelas ini, untuk mengetahui adanya autokoelasi adalah dengan menggunakan Durbin-Watson (DW) Statistic.

\section{Tabel Uji Durbin-Watson (DW)}

Dependent Variable: Y

Method: Panel Least Squares

Date: 12/06/14 Time: 11:22

Sample: 20092013

Periods included: 5

Cross-sections included: 11

Total panel (balanced) observations: 55

\begin{tabular}{llll} 
R-squared & 0.100116 & Mean dependent var & 3.327273 \\
Adjusted R-squared & 0.047181 & S.D. dependent var & 0.579097 \\
S.E. of regression & 0.565271 & Akaike info criterion & 1.766923 \\
Sum squared resid & 16.29608 & Schwarz criterion & 1.912911 \\
Log likelihood & -44.59039 & Hannan-Quinn criter. & 1.823378 \\
F-statistic & 1.891320 & Durbin-Watson stat & 0.765246 \\
Prob(F-statistic) & 0.142775 & & \\
\hline \hline
\end{tabular}

Dari tabel di atas terlihat nilai durbin wastonsebesar 0,7652terletak diantara dL 0,5948 dU 1,9280 yang menunjukkan bahwa model initidak menghasilkan kesimpulan yang pasti(Tanpa Kesimpulan) untuk melihat adanya autokorelasinya. Artinya dalam daerah ini, hipotesis nol tersebut tidak ditolak tetapi juga tidak diterima (Lind et al, 2007: 255)

\section{Pengujian Koefisien Regresi}

Untuk mengetahui bagaimana pengaruh dari variabel-variabel bebas terhadap variabel terikat pada penelitian ini, maka data diolah dengan menggunakan metode analisis regresi berganda.Seperti telah diketahui sebelumnya bahwa variabel $\mathrm{X}$ (bebas) pada penelitian ini adalahprofitabilitas, leverage, dan likuiditas.Sedangkan variabel $\mathrm{Y}$ (terikat) pada penelitian ini adalahkinerja lingkungan perusahaan. Model regresi berganda yang dibentuk adalah :

$$
\mathrm{Y}^{\prime}=\mathrm{a}+\mathrm{b}_{1} \mathrm{X}_{1}-\mathrm{b}_{2} \mathrm{X}_{2}+\mathrm{b}_{3} \mathrm{X}_{3}+\varepsilon
$$

Berdasarkan olah data dengan program Eviews 7, maka didapat hasil:

\section{Tabel Output SPSS Regresi Linear Berganda}

Dependent Variable: Y

Method: Panel Least Squares

Date: 12/06/14 Time: 11:22

Sample: 20092013

Periods included: 5

Cross-sections included: 11

\begin{tabular}{lll}
\hline \hline Variable & \multicolumn{2}{c}{ CoefficientStd. Error } \\
\hline \hline $\mathrm{C}$ & 3.606327 & 0.338190
\end{tabular}




\begin{tabular}{lll}
$\mathrm{X} 1$ & 0.168910 & 1.452563 \\
$\mathrm{X} 2$ & -0.780972 & 0.458598 \\
$\mathrm{X} 3$ & $4.49 \mathrm{E}-06$ & $9.02 \mathrm{E}-06$ \\
\hline \hline
\end{tabular}

Berdasarkan tabel hasil perhitungan diatas maka diperoleh persamaan regresi berganda sebagai berikut:

$$
\mathrm{Y}^{\prime}=3,61+0,17 \mathrm{x}-0,78 \mathrm{x}+4,49 x+\varepsilon
$$

Dari persamaan regresi tersebut, terlihat bagaimana pengaruh profitabilitas $(\mathrm{X} 1)$ leverage $(\mathrm{X} 2)$ dan likuiditas $\left(\mathrm{X}_{3}\right)$ terhadap kinerja lingkungan (Y).Hasil diatas memberikan pemahaman bahwa jika tidak terjadi profitabilitas, leverage, dan likuiditas, maka besarnya kinerja lingkungan diprediksi sebesar 3,61 berdasarkan nilai konstanta (a). Selanjutnya nilai koefisien profitabilitas (b1) = 0,17 menunjukkan bahwa setiap penambahan satu satuan maka akan meningkatkan kinerja lingkungan sebesar 0,17 satuan dengan asumsi bahwa nilai konstanta tidak berubah.Demikian pula dengan nilai koefisien regresi leverage (b2) $=-0,78$ menunjukkan bahwa setiap penambahan satu satuan leverage maka akan menurunkan kinerja lingkungan sebesar 0,78 satuan dengan asumsi bahwa nilai konstanta tidak berubah. Dan dengan nilai koefisien regresi likuiditas(b3) $=$ 4,49 menunjukkan bahwa setiap penambahan satu satuan likuiditas maka akan mmeningkatkan kinerja lingkungan sebesar 4,49 satuan dengan asumsi bahwa nilai konstanta tidak berubah. Dapat disimpulkan bahwa terdapat pengaruh antara profitabilitas, leverage, dan likuiditas terhadap kinerja lingkungan.

\section{Pengujian Parsial (Uji t )}

Berikut adalah table t hasil perhitungan Eviews 7untuk hipotesis ini :

\section{Tabel Pengujian Parsial}

Dependent Variable: Y

Method: Panel Least Squares

Date: 12/06/14 Time: 11:22

Sample: 20092013

Periods included: 5

Cross-sections included: 11

Total panel (balanced) observations: 55

\begin{tabular}{lllll}
\hline \hline Variable & \multicolumn{2}{c}{ Coefficient Std. Error } & t-Statistic & Prob. \\
\hline \hline C & 3.606327 & 0.338190 & 10.66360 & 0.0000 \\
X1 & 0.168910 & 1.452563 & 0.116284 & 0.9079 \\
X2 & -0.780972 & 0.458598 & -1.702955 & 0.0947 \\
X3 & $4.49 E-06$ & $9.02 E-06$ & 0.498104 & 0.6206 \\
\hline \hline
\end{tabular}

Sumber: Eviews 7. Data diolah

Berdasarkan output SPSS diperoleh nilai signifikansi untuk profitabilitas terhadap kinerja lingkungan $=0,90>0.05$ dan diperoleh nilai thitung $(0,116)<$ ttabel $(2,008)$ maka dapat dikatakan koefisien regresi tidak signifikan. Sedangkan nilai signifikansi untuk leverage terhadap kinerja lingkungan $=0,09>0.05$ dan diperoleh nilai thitung $(-1,702)<$ ttabel $(2,008)$ maka dapat dikatakan koefisien regresi tidak signifikan. Dan nilai signifikansi untuk likuiditas terhadap kinerja 
lingkungan $=0,62>0.05$ dan diperoleh nilai thitung $(0,498)<$ ttabel $(2,008)$ maka dapat dikatakan koefisien regresi tidak signifikan. Disimpulkan bahwa tidak terdapat pengaruh yang signifikan antara profitabilitas, leverage, dan likuiditasterhadap kinerja lingkungan secara parsial.

\section{Pengujian Simultan (Uji F)}

Berikut adalah tableF hasil perhitungan Eviews 7untuk hipotesis ini

\section{Tabel Pengujian Simultan}

Dependent Variable: Y

Method: Panel Least Squares

Date: 12/06/14 Time: 11:22

Sample: 20092013

Periods included: 5

Cross-sections included: 11

Total panel (balanced) observations: 55

\begin{tabular}{lllll}
\hline \hline Variable & \multicolumn{2}{l}{ Coefficient Std. Error } & t-Statistic & Prob. \\
\hline \hline $\mathrm{C}$ & 3.606327 & 0.338190 & 10.66360 & 0.0000 \\
$\mathrm{X} 1$ & 0.168910 & 1.452563 & 0.116284 & 0.9079 \\
$\mathrm{X} 2$ & -0.780972 & 0.458598 & -1.702955 & 0.0947 \\
$\mathrm{X} 3$ & $4.49 \mathrm{E}-06$ & $9.02 \mathrm{E}-06$ & 0.498104 & 0.6206 \\
\hline \hline R-squared & 0.100116 & Mean dependent var & 3.327273 \\
Adjusted R-squared & 0.047181 & S.D. dependent var & 0.579097 \\
S.E. of regression & 0.565271 & Akaike info criterion & 1.766923 \\
Sum squared resid & 16.29608 & Schwarz criterion & 1.912911 \\
Log likelihood & -44.59039 & Hannan-Quinn criter. & 1.823378 \\
F-statistic & 1.891320 & Durbin-Watson stat & 0.765246 \\
Prob(F-statistic) & 0.142775 & & & \\
\hline \hline
\end{tabular}

Sumber: Eviews 7. Data diolah

Berdasarkan output Eviews diperoleh nilai signifikansi $=0,14>0.05$ dan diperoleh nilai Fhitung $(1,891)$ < Ftabel $(2,79)$ maka dapat dikatakan koefisien regresi tidak signifikan. Disimpulkan bahwa tidak terdapat pengaruh yang signifikan antara profitabilitas, leverage, dan likuiditasterhadap kinerja lingkungan secara simultan.

\section{Pengujian Koefisien Determinasi}

Hasil pengujian diperoleh sebagai berikut:

TabelOutput Pengujian Koefisien Determinasi

Dependent Variable: Y

Method: Panel Least Squares

Date: 12/06/14 Time: 11:22

Sample: 20092013

Periods included: 5

Cross-sections included: 11

Total panel (balanced) observations: 55

\begin{tabular}{lrll}
\hline \hline R-squared & 0.100116 & Mean dependent var & 3.327273 \\
Adjusted & R-0.047181 & S.D. dependent var & 0.579097
\end{tabular}


squared

\begin{tabular}{llll} 
S.E. of regression & 0.565271 & Akaike info criterion & 1.766923 \\
Sum squared resid & 16.29608 & Schwarz criterion & 1.912911 \\
Log likelihood & -44.59039 & Hannan-Quinn criter. & 1.823378 \\
F-statistic & 1.891320 & Durbin-Watson stat & 0.765246 \\
Prob(F-statistic) & 0.142775 & & \\
\hline \hline
\end{tabular}

Sumber: Eviews 7. Data diolah

Dari hasil pengujian terlihat nilai 0,047 yang berarti $4,7 \%$ kinerja lingkungan Badan Usaha Milik Negara (BUMN) sektor manufaktur dapat dijelaskan oleh variasi dari ketiga variabel independen profitabilitas, leverage, dan likuiditas. Sedangkan sisanya 95,3\% dijelaskan oleh variabel lain yang tidak diteliti dalam penelitian ini.

\section{Pembahasan}

\section{Pengaruh Profitabilitas, Leverage, dan Likuiditas terhadap Kinerja Lingkungan Secara Parsial Profitabilitas terhadap Kinerja Lingkungan}

Perusahaan yang memiliki kemampuan kinerja keuangan yang baik, akan identik dengan upaya-upaya untuk melakukan pengungkapan yang lebih luas. Luasnya pengungkapan yang dilakukan oleh perusahaan adalah upaya untuk memperoleh dukungan dan mencari simpati para stakeholder-nya. Perusahaan dengan kinerja yang tinggi akan meningkatkan nilai perusahaan dalam proses pembentukan image yang sangat berpengaruh untuk mendapat kepercayaan dari para stakeholder. Kinerja perusahaan yang baik, dapat dicerminkan melalui tingkat profitabilitas yang akan diperoleh dari waktu ke waktu. Dengan kinerja perusahaan yang baik yang dicerminkan oleh tingkat profitabilitas juga akan mempengaruhi tingkat kinerja lingkungan perusahaan pula. Jadi semakin manejemen berusaha meningkatkan tingkat profitabilitas perusahaan, ukuran dari kinerja lingkungan akan semakin membaik/tinggi.

Penelitian ini bertujuan untuk mengetahui seberapa pengaruh profitabilitas, leverage, dan likuiditas terhadap kinerja lingkungan pada Badan Usaha Milik Negara (BUMN) sektor manufaktur pada tahun 2009-2013.Data yang digunakan diperoleh dari laporan keuangan tahunan yang diakses dari www.bumn.go.id atau website masing-masing perusahaan.Perusahaan yang dijadikan sampel penelitian ini berjumlah 11 perusahaan.Untuk mengetahui pengaruh antara variabel tersebut secara parsial, peneliti memakai alat uji t untuk menghitungnya. Hasilnya adalah terdapat pengaruh profitabilitas terhadap kinerja lingkungan tetapi tidak terdapat pengaruh yang signifikan. .

Hasil penelitian ini sejalan dengan sejalan dengan teori yang menyatakan salah satu pengukuran kinerja lingkungan salah satunya dengan profitabilitas yang menyebabkan apabila tingkat profitabilitas perusahaan meningkat, ukuran dari kinerja lingkungan akan semakin membaik/tinggi. Dan juga sejalan dengan penelitian Anggi Martia (2011) Penelitian ini juga menyatakan bahwa secara parsial ROA (Return On Asset) berpengaruh positif signifikan terhadap kinerja lingkungan, dimana ROA ini adalah sebagai rasio yang dipakai utk mengukur profitabilitas. Tetapi tidak sejalan dengan penelitian Greg Filbeck \& Raymond F. Gorman (2004) yang menunjukan tidak ditemukannya hubungan positif antara kinerja lingkungan dan keuangan yang berarti kedua variabel ini tidak saling 
mempengaruhi satu sama lain, untuk kinerja keuangan sendiri dapat diukur dari tingkat profitabilitas.

Dalam penelitian ini, untuk hasil pengaruh yang tidak signifikan disinyalir dikarenakan pada BUMN sektor manufaktur periode 2009-2013 tingkat laba bersihnya yang sangat beragam dan ada beberapa yang terdapat kesenjangan dari jumlah laba bersih dari masing-masing perusahaan, serta ukuran asset yang berbeda-beda satu sama lain perusahaan dan terlampau jauh ukurannya. Dan hal ini mempengaruhi tingkat profitabilitas perusahaan karena merupakan komponen rasio return on asset

\section{Leverage terhadap Kinerja Lingkungan}

Semakin tinggi tingkat leverage, maka akan ada kecenderungan perusahaan berusaha untuk melaporkan profitabilitasnya agar tetap tinggi. Hal ini dikarenakan, tingkat profitabilitas yang tinggi akan mencerminkan kondisi keuangan perusahaan yang kuat sehingga dapat meyakinkan perusahaan dalam memperoleh pinjaman dari para stakeholder-nya. Bahkan, semakin tinggi tingkat leverage semakin besar kemungkinan perusahaan akan melanggar perjanjian kredit, sehingga akan berusaha untuk melaporkan laba sekarang lebih tinggi. Para stakeholder perusahaan, akan lebih percaya dan memilih untuk menginvestasikan dananya pada perusahaan-perusahaan yang memiliki kondisi keuangan yang sehat dan baik. Hal ini berarti, manajer perusahaan untuk mendapatkan laba yang tinggi harus mengurangi biaya-biaya (termasuk biaya untuk mengungkapkan laporan sosial dan lingkungan).

Penelitian ini bertujuan untuk mengetahui seberapa pengaruh profitabilitas, leverage, dan likuiditas terhadap kinerja lingkungan pada Badan Usaha Milik Negara (BUMN) sektor manufaktur pada tahun 2009-2013.Data yang digunakan diperoleh dari laporan keuangan tahunan yang diakses dari www.bumn.go.id atau website masing-masing perusahaan.Perusahaan yang dijadikan sampel penelitian ini berjumlah 11 perusahaan.Untuk mengetahui pengaruh antara variabel tersebut secara parsial, peneliti memakai alat uji t untuk menghitungnya. Hasilnya adalah terdapat pengaruh leverage terhadap kinerja lingkungan tetapi tidak terdapat pengaruh yang signifikan.

Hasil penelitian ini sejalan dengan teori yang menyatakan bahwa ada hubungan negatif antara pengungkapan sosial yang merupakan kriteria kinerja lingkungan dengan tingkat leverage keuangan, yang berarti bahwa rasio yang lebih tinggi utang / ekuitas akan mengakibatkan pengungkapan sosial yang lebih rendah karena semakin tinggi leverage adalah lebih perusahaan akan mematuhi perjanjian kredit. Sehingga perusahaan harus memberikan pengembalian yang lebih tinggi pada saat ini daripada laba masa depan. Agar perusahaan dapat memberikan keuntungan yang lebih tinggi, perusahaan harus mengurangi biaya (termasuk biaya informasi lingkungan). Dan penelitian ini juga mendukung penelitian Connors, Elizabeth \& Gao, Lucia S. (2011) yang menemukan hubungan yang signifikan antara leverage dan kinerja lingkungan.

\section{Likuiditas terhadap Kinerja Lingkungan}

Perusahaan dengan tingkat likuiditas yang tinggi berarti menandakan kemampuan yang besar untuk membayar kewajiban-kewajiban jangka pendeknya tepat waktu. Perusahaan yang memiliki likuiditas yang tinggi akan menciptakan image yang kuat dan positif dimata para stakeholder-nya. Stakeholder tentunya akan semakin berpihak dan memberikan dukungannya pada perusahaan- 
perusahaan yang memiliki image yang semakin baik dan kuat. Upaya-upaya yang dapat ditempuh perusahaan untuk membentuk dan memperkuat image-nya adalah melalui pembuatan laporan-laporan tambahan. Salah satu upaya pengungkapan yang dapat dilakukan oleh perusahaan adalah pengungkapan sosial dan lingkungan yang merupakan salah satu kriteria dalam pengukuran kinerja lingkungan.

Penelitian ini bertujuan untuk mengetahui seberapa pengaruh profitabilitas, leverage, dan likuiditas terhadap kinerja lingkungan pada Badan Usaha Milik Negara (BUMN) sektor manufaktur pada tahun 2009-2013.Data yang digunakan diperoleh dari laporan keuangan tahunan yang diakses dari www.bumn.go.id atau website masing-masing perusahaan.Perusahaan yang dijadikan sampel penelitian ini berjumlah 11 perusahaan.Untuk mengetahui pengaruh antara variabel tersebut secara parsial, peneliti memakai alat uji t untuk menghitungnya. Hasilnya adalah terdapat pengaruhlikuiditas terhadap kinerja lingkungan tetapi tidak terdapat pengaruh yang signifikan.

Hasil penelitian ini sejalan dengan teori yang menyatakan bahwa tingkat likuiditas yang tinggi akan menunjukkan kuatnya kondisi keuangan perusahaan. Perusahan dengan kondisi seperti ini cenderung akan melakukan pengungkapan informasi yang lebih luas kepada pihak luar karena ingin menunjukkan bahwa perusahaan itu kredibel. Salah satu upaya pengungkapan yang dapat dilakukan oleh perusahaan adalah pengungkapan sosial dan lingkungan yang merupakan salah satu kriteria dalam pengukuran kinerja lingkungan. Dan sejalan dengan penelitian Dietrich Earnhart \& Lubomir Lizal (2006) yang memberikan bukti bahwa kesuksesan kinerja keuangan meningkatkan kinerja lingkungan di masa depan, yang dilihat dari likuiditas

\section{Pengaruh Profitabilitas, Leverage, dan Likuiditas terhadap Kinerja Lingkungan Secara Simultan}

Penelitian ini bertujuan untuk mengetahui seberapa pengaruh profitabilitas, leverage, dan likuiditas terhadap kinerja lingkungan pada Badan Usaha Milik Negara (BUMN) sektor manufaktur pada tahun 2009-2013.Data yang digunakan diperoleh dari laporan keuangan tahunan yang diakses dari www.bumn.go.id atau website masing-masing perusahaan.Perusahaan yang dijadikan sampel penelitian ini berjumlah 11 perusahaan.Untuk mengetahui pengaruh antara variabel tersebut secara simultan, peneliti memakai alat uji f untuk menghitungnya. Hasilnya adalah terdapat pengaruh profitabilitas, leverage, dan likuiditas terhadap kinerja lingkungan tetapi tidak terdapat pengaruh yang signifikan.

Hasil tersebut terlihat dari angka regresi sebesar 0.57 yang menyatakan adanya pengaruh profitabilitas, leverage, dan likuiditas terhadap kinerja lingkungan dengan tingkat signifikansi 0.14 yang menyatakan pengaruh tersebut tidak signifikan. Dari hasil pengujian koefisien determinasi terdapat nilai 0,047 yang berarti 4,7\% kinerja lingkungan Badan Usaha Milik Negara (BUMN) sektor manufaktur dapat dijelaskan oleh variasi dari ketiga variabel independen profitabilitas, leverage, dan likuiditas. Sedangkan sisanya 95,3\% dijelaskan oleh variabel lain yang tidak diteliti dalam penelitian ini. Dari hasil pengujian diperoleh bahwa hipotesis yang menyatakan bahwa Profitabilitas, leverage, dan likuiditas mempunyai pengaruh terhadap kinerja lingkungan secara simultan adalah diterima meskipun tidak dalam taraf signifikan. 


\section{SIMPULAN}

\section{Simpulan}

Dari hasil analisa dan pengolahan data pada penelitian tentang "Pengaruh Profitabilitas, Leverage Dan Likuiditas Terhadap Kinerja Lingkungan (Studi pada Badan Usaha Milik Negara (BUMN) Sektor Manufaktur Periode 2009-2013)". Makadapatditarikkesimpulansebagaiberikut :

1. Profitabilitas BUMN sektor manufaktur cenderung mengalami fluktuatif dalam periode 2009-2013, dan rata-rata profitabilitas yang di hitung dengan rasio ROA pada BUMN sektor manufaktur pada tahun 2013 adalah 0,1127. Leverage BUMN sektor manufaktur cenderung mengalami fluktuatif dalam periode 2009-2013, dan rata-rata leverage yang di hitung dengan rasio utang pada BUMN sektor manufaktur pada tahun 2013 adalah 0,4303. likuiditas BUMN sektor manufaktur cenderung mengalami peningkatan dalam periode 2009-2013, dan rata-rata likuiditas yang di hitung dengan rasio lancar pada BUMN sektor manufaktur pada tahun 2013 adalah 3,0857. Peringkat kinerja lingkungan BUMN sektor manufaktur cenderung mengalami peningkatan yang tidak terlalu signifikan dalam periode 2009-2013, dan rata-rata peringkat kinerja lingkungan yang di hitung dengan PROPER pada BUMN sektor manufaktur pada tahun 2013 adalah 4 (HIJAU).

2. Profitabilitas berpengaruh secara tidak signifikan terhadap kinerja lingkungan, artinya semakin tinggi rasio profitabilitas.Leverage berpengaruh secara tidak signifikan terhadap kinerja lingkungan. Likuiditas berpengaruh secara tidak signifikan terhadap kinerja lingkungan. Profitabilitas, leverage, dan likuiditas mempunyai pengaruh terhadap kinerja lingkungan secara simultan meskipun tidak dalam taraf signifikan

\section{Saran}

Berdasarkan hasil penelitian yang telah dilakukan dan kesimpulan yang telah diperoleh, maka penulis memiliki beberapa saran yang berhubungan dengan pengaruh profitabilitas, leverage dan likuiditas terhadap kinerja lingkungan, diantaranya:

1. Hendaknya perusahaan senantiasa memperhatikan aspek kinerja lingkungan untuk memenuhi tujuan utama perusahaan yaitu triple bottom line (profit, people, dan planet). Dalam upaya mempertahankan, dan meningkatkan kinerja lingkungan, perusahaan sebaiknya lebih berhati-hati dalam mengelola profitabilitas, leverage, dan likuiditas nya dengan baik sehingga perusahaan akan terus meningkatkan pengungkapan sosial dan lingkungannya yang menjadi indikator dari kinerja lingkungan.

2. Bagi investor dan kreditur hendaknya lebih bijaksana dalam berinvestasi dengan melihat kinerja perusahaan yang tidak hanya mengutamakan aspek ekonomi atau kinerja keuangan tetapi juga memperhatikan dampak operasionalnya terhadap aspek sosial dan lingkungan, karena dengan begitu investor dan kreditur turut berperan dalam menjaga keberlanjutan aspek kinerja lingkungan perusahaan. 
3. Pemerintah yang di wakili oleh Kementrian Lingkungan Hidup hendaknya meningkatkan regulasi, pengawasan dan tindak hukum yang tegas terhadap pelanggaran kinerja lingkungan pada perusahaan di Indonesia sehingga praktik manajemen lingkungan di Indonesia semakin meningkat.

\section{DAFTAR PUSTAKA}

Anggi, Martia. (2011). Pengaruh ROA, Total Asset dan ISO 14001 terhadap Kinerja Lingkungan. Universitas Padjajaran.

Badan Standardisasi Nasional. (2005). Sistem Manajemen Lingkungan Persyaratan dan Panduan Pengguna (SNI 19-14001-2005).

Bergmiller, Gary G. (2009). Lean Manufacturing Transcendence to Green Manufacturing: Corelating Difussion of Lean and Green Manufacturing System. A dissertation submitted in partial fullfillment Doctor Philosophy at University of South Florida.

Brigham, Eugene F dan Houston, Joel F. (2010). Dasar-Dasar Manajemen Keuangan, Edisi ke 11 Buku 1. Jakarta: Salemba Empat.

Connors, Elizabeth and Gao, L.S. (2011). Corporate Environmental Performance, Disclosure and Leverage: An Integrated Approach. International Review of Accounting, Banking and Finance, Fall 2011, Vol. 3 Issue 3.

Earnhart, Dietrich and Lizal, Lubomir. (2006). Effects of ownership and financial performanceon corporate environmental performance. Journal of Comparative Economics 34, 111-129, Elsevier Inc.

Filbeck, Greg and Gorman Raymond . (2004). The Relationship Between The Environmental And Financial Performance Of Public Utilities. Environmental and Resource Economics: 137-157, Kluwer Academic Publishers, Netherlands.

Gitman, Lawrence J. (2003). Principles of Managerial Finance, 10Th Edition. United States: Pearson Education Inc.

Ikhsan, Arfan. (2009). Akuntansi Manajemen Lingkungan. Yogyakarta: Graha Ilmu.

Hanafi, Mahmud M. (2008). Manajemen Keuangan. Yogyakarta: BPFE.

Ignatius Bondan. Et al. (2006). Pengaruh Environmental Performance terhadap Environmental Disclosure dan Economic Performance. Simposium Nasional Akuntansi9, Padang.

Imam Ghozali. (2007). Aplikasi Analisis Multivariat dengan Program SPSS, Edisi ketiga. Semarang : Badan Penerbit Universitas Diponegoro.

Lind, Douglas A. Marchal, William G \& Wathen, Samuael A. (2007). TeknikTeknik Statistik dalam Bisnis dan Ekonomi, Buku Kedua Edisi Ketigabelas. Jakarta: Salemba Empat.

Naser, K.Al-Hussaini, A. Al-Kwari, D.\& Nuseibeh, R. (2006). Determinans of Corporate Social Disclosure in Developing Countries: The Case of Qatar. Advance in International Accounting, 19, 1-23.

Nur Indriantoro dan Bambang Supomo. (2012). Metodologi Penelitian Bisnis Untuk Akuntansi dan Manajemen. Yogyakarta: BPFE.

Sugiyono. (2007). Metode Penelitian Bisnis. Bandung: Alfabeta. Sugiyono. (2011). Metode Penelitian Bisnis. Bandung: Alfabeta.

Susi, Sarumpaet. (2005). The Relationship Between Environmental Performance And Financial Performance Of Indonesian Companies. JURNAL AKUNTANSI \& KEUANGAN, VOL. 7, NO. 2, NOVEMBER 2005. 
Sutrisno.(2000). Manajemen Keuangan. Yogyakarta: Ekonosia.

Syamsudin, Lukman. (2001). Manajemen Keuangan Perusahaan (Konsep Aplikasi Dalam Perencanaan, Pengawasamn, dan Pengambilan Keputusan). Jakarta: PT.Raja Grafindo Persada.

Undang-Undang Republik Indonesia No. 23 Tahun 1997 